\title{
In Memory of Brigitte Haar
}

\section{Birgitta Wolff ${ }^{1}$}

Published online: 22 February 2021

(c) The Author(s) 2021

A university endeavours to be a microcosm that reflects society as a whole. And what is more natural than the fact that celebrations also belong to the reality of life? The occasions for academic celebrations vary: celebrations arise from happy occasions such as passing an exam or receiving a doctoral degree; but 'celebrations' in the form of symposiums and conferences are also held on sad occasions, such as when someone is torn from our midst. But no matter the occasion: an academic celebration always celebrates the Gordian knot of human being, education and knowledge/science. And just as the famous ancient knot was tied to a post-that is to the shaft of a chariot - the life of Brigitte Haar played out primarily between two poles: between hiking and science, and in the latter between the interwoven lines of law and economics.

Long mountain tours-which took her to her limits-always had an enormous attraction for Brigitte Haar. These challenging hikes were more than mere leisure activity-for Brigitte Haar they were an energy source that never ran dry. And this was the energy that allowed her to also be immensely productive as a scientist.

Just as Brigitte Haar tested her personal limits during her mountain tours, she pushed limits on knowledge as a scientist, and as professor in Goethe University's self-administration, she converted (international) borders into bridges. Brigitte Haar was a 'border crosser' with heart and soul, and in the most positive sense of the phrase.

I experienced this characterisation in the dedication Brigitte Haar brought to academic self-administration. She was committed, and she contributed to 'her' university beyond the usual degree: she was Vice President of Internationalisation from 2015 to 2018.

In 2004, Brigitte Haar accepted the appointment to Frankfurt am Main. She subsequently held guest professorships at the University of Pennsylvania and Columbia Law School, where she was principal investigator of the Global Law in Finance network. At Goethe University, the graduate school Law and Economics of Money and Finance was particularly dear to her heart, and she had every right to be proud of its acquisition, in which she was the driving motor. In addition, she was a member of

Birgitta Wolff

wolff@pvw.uni-frankfurt.de

1 Former President of Goethe University Frankfurt, Frankfurt, Germany 
the House of Finance's executive board beginning in 2009, and became a member of the scientific board of SAFE in 2012.

With her interests and personal characteristics, Brigitte Haar was predestined for the newly created department 'Internationalisation': she was equipped with international experience both personally and in her academic field. This gave her an international perspective from the bottom up when she was Vice President. From the perspective of the Executive Board - the top-down perspective-she had her eye on the specifically decentral structure of our university and allowed the faculties complete freedom of design, relying on incentives rather than requirements.

Brigitte Haar was educated in law (Volljurist), and she embodied this in the best sense: her sentences were well-considered, her use of language was accurate. The committee work in academic self-administration lives precisely from plausible and well-considered views being put forward emphatically. And we all know that-and how-determined Brigitte Haar could take a position and set limits: you had to argue with her-but always knowing that it was a striving together that had the goal of shaping Goethe University together. The university process of shaping opinion and policy depends on rule-following combatants of this kind, so that each person's opinion can be developed in discourse through pros and cons.

Brigitte Haar's agenda as Vice President for Internationalisation was not only characterised by the idea of representation, but by her high ethical standards and her sense of the common good. She implemented the latter by creating opportunities for others to share responsibility. A perfect example of this are the diplomat matinees that Brigitte Haar created: by inviting, for example, the consulate generals from France, Brazil and Mexico to correspondingly selected country-specific events, she brought Goethe University into play as diplomatic actor: 'science diplomacy'.

Above all, however, Brigitte Haar was crucial as impulse-giver for the continuing networking of our university: for example, by further developing central strategic partnerships from previous executive boards. She organised events with Goethe University partners (University of Pennsylvania, Philadelphia University, University of Birmingham, University of Toronto and University of Tel Aviv) and extended these programmes with internationally visible events that acted as beacons-such as the Frankfurt Summer Academy on Global Justice.

Brigitte Haar's understanding as Goethe University Vice President is best formulated by herself: 'For me, internationalisation means [...] that all actors, and the administration in particular, conceive of internationalism as a necessary dimension of their actions' (Brigitte Haar). We called this 'internationalisation mainstreaming'.

Brigitte Haar was a perfect fit in the Executive Board precisely because the borders between Brigitte Haar the jurist, the scientist and the discourse partner were fluid. We thank her!

Funding Open Access funding enabled and organized by Projekt DEAL.

Open Access This article is licensed under a Creative Commons Attribution 4.0 International License, which permits use, sharing, adaptation, distribution and reproduction in any medium or format, as long as you give appropriate credit to the original author(s) and the source, provide a link to the Creative 
Commons licence, and indicate if changes were made. The images or other third party material in this article are included in the article's Creative Commons licence, unless indicated otherwise in a credit line to the material. If material is not included in the article's Creative Commons licence and your intended use is not permitted by statutory regulation or exceeds the permitted use, you will need to obtain permission directly from the copyright holder. To view a copy of this licence, visit http://creativecommons.org/ licenses/by/4.0/.

Publisher's Note Springer Nature remains neutral with regard to jurisdictional claims in published maps and institutional affiliations. 